\title{
Quantitative Evaluation of Inflammatory Response in Rats Submitted to the Abdominal Wall Surgery Using Peritoneum of Paca Preserved in $300 \%$ Supersaturated Solution of Sucrose or $\mathbf{9 8 \%}$ Glycerin
}

\author{
Leonardo Martins Leal ${ }^{*}$, Alessandra Regina Scavone Ferreira ${ }^{2}$, \\ Tais Harumi de Castro Sasahara ${ }^{3}$, Aliny Antunes Barbosa Lobo Ladd3, \\ Paola Castro Moraes², Márcia Rita Fernandes Machado² \\ ${ }^{1}$ Ingá University Center (UNINGÁ), Maringá, Brazil \\ ${ }^{2}$ University of the State of São Paulo (UNESP), Jaboticabal, Brazil \\ ${ }^{3}$ University of São Paulo (USP), São Paulo, Brazil \\ Email: ^leonardo.vet@hotmail.com
}

How to cite this paper: Leal, L.M., Ferreira, A.R.S, de Castro Sasahara, T.H., Ladd, A.A.B.L., Moraes, P.C. and Machado, M.R.F. (2018) Quantitative Evaluation of Inflammatory Response in Rats Submitted to the Abdominal Wall Surgery Using Peritoneum of Paca Preserved in 300\% Supersaturated Solution of Sucrose or $98 \%$ Glycerin. Open Journal of Animal Sciences, 8, 439-449.

https://doi.org/10.4236/ojas.2018.84033

Received: September 29, 2018

Accepted: October 26, 2018

Published: October 29, 2018

Copyright $\odot 2018$ by authors and Scientific Research Publishing Inc. This work is licensed under the Creative Commons Attribution International License (CC BY 4.0).

http://creativecommons.org/licenses/by/4.0/

\section{(c) (i) Open Access}

\begin{abstract}
This study aimed to quantitative evaluate the implantation of paca's peritoneum, a new biomaterial option, preserved in $300 \%$ supersaturated sugar solution or $98 \%$ glycerin on the abdominal wall of Wistar rats. 60 males, weighing between 150 and $200 \mathrm{~g}$, are organized into the following experimental groups: control group (GI); group peritoneum preserved in 300\% supersaturated sugar solution (GII); and group peritoneum preserved in $98 \%$ glycerin (GIII). Each group had 20 animals. Five rats from each group underwent euthanasia at four different moments: $7^{\text {th }}, 15^{\text {th }}, 30^{\text {th }}$, and $60^{\text {th }}$ post-operatory day for histological and stereological evaluations of the graft/native tissue interface. On histological examination, one found out an extensive presence of inflammatory infiltrate at the early periods $\left(7^{\text {th }}\right.$ and $15^{\text {th }}$ day) and an extensive presence of connective tissue at the late moments $\left(30^{\text {th }}\right.$ and $60^{\text {th }}$ day). Through stereological analysis, one found out that the number of mononuclear cells decreased throughout the evaluation moments. One concluded that the paca's peritoneum as a biological membrane preserved in $98 \%$ glycerin, when implanted on the abdominal wall of rats, microscopically allowed one to obtain, through stereological analyses, a lower inflammatory response than the paca's peritoneum preserved in 300\% supersaturated sugar solution.
\end{abstract}

\section{Keywords}

Healing, Pathology, Graft, Wild, Stereology 


\section{Introduction}

The search for biological membranes having, at the same time, low antigenicity and high resistance, as well as preservation means with high stabilizing power, preventing the complete breakdown of tissues and the growth of microorganisms, besides preserving maximum cellular integrity, increasing the tensile strength of tissues, and acting for a lengthen period of time is constant [1] [2].

Biological membranes of canines, sheep, cattle, horses, and pigs, preserved in different media, have been studied for about five decades [1] [3]- [9].

In the search both for alternative biological material to perform implantations and new options of animal experimentation models, there emerges the lowland paca (Cuniculus paca, Linnaeus 1766), a species belonging to the rodent order, typical of tropical regions [10] observed in a large part of Brazil and Latin America [11] [12] [13], which, in addition to its commercial importance as a protein source, can also play a role in science, since it presents characteristics that meet the conditions assigned to an experimental animal model, such as: suitable size, wide geographical distribution, adaptation to various environments, and varied nutrition [14].

Leal et al. (2014) [15] already have compared quantitatively the use of peritoneum of paca preserved in $300 \%$ supersaturated sucrose solution or $98 \%$ glycerin implanted in the abdominal wall of rats and they observed, in macroscopic analysis, that despite the adverse reaction observed in $57.5 \%$ of animals that received the membrane in $95 \%$ of these animals had satisfactory wound healing. On histological analysis, it was observed the presence of large inflammatory infiltrate in the early periods ( 7 and 15 days) and large presence of connective tissue in the closing stages ( 30 and 60 days).

Stereology provides meaningful quantitative descriptions of the geometry of 3D structures from measurements that are made on 2D images [16] [17] [18] [19].

The two basic concepts of stereology are determinations "without deviation" (without bias) and low variability. For conducting the stereological study, there's a need for using systematically and uniformly random samples, where all sampling fields have the same probability of being selected, from the collection time to the final processing of data [20].

Stereology presents advantages over qualitative studies, such as histology, since the results are quantitative instead of qualitative, being, therefore, replicable in any other laboratory, in addition to the well-defined statistical groundwork which supports this method. For evaluating the inflammatory response, stereology was used by [21] in a comparative study of the healing process in different suture wires in the repair of hypospadia in rats.

Thus, given the increasing use of biological materials in reconstructive surgeries and the constant search for conservation methods focused on the various tissues [2], aimed to compare the lowland paca's peritoneum preserved in a $300 \%$ supersaturated sugar solution and preserved in $98 \%$ glycerin implanted on 
the abdominal wall of rats, taking into account the inflammatory response through quantitative analysis by applying sterology.

\section{Material and Methods}

This methodology was approved by the Ethics Committee on Animal Use (CEUA) of College of Agriculture and Veterinary Sciences (FCAV/UNESP), in Jaboticabal, São Paulo, Brazil, according to the Brazilian College of Experimentation (COBEA), under the Reference 012730/11.

One used 60 Wistar rats, male, weighing between 150 and $200 \mathrm{~g}$. The animals were kept in individual $30 \mathrm{~cm} \times 20 \mathrm{~cm} \times 18 \mathrm{~cm}$ cages located at the Vivarium of the Department of Animal Morphology and Physiology of FCAV/UNESP, and they received food and water at ease.

The animals were divided, according to the treatments, into three experimental groups: GI-control group $(\mathrm{n}=20)$; GII-group peritoneum preserved in $300 \%$ supersaturated sugar solution $(n=20)$; and GIII-group peritoneum preserved in $98 \%$ glycerin $(n=20)$. Then, each group was divided into four subgroups $(n=5)$ related to the euthanasia moment for macroscopic and microscopic evaluations: M7-at the $7^{\text {th }}$ day; M15-at the $15^{\text {th }}$ day; M30-at the $30^{\text {th }}$ day; and M60-at the $60^{\text {th }}$ post-operatory day.

The lowland pacas used in the experiment were obtained from the Wild Animals Sector of FCAV/UNESP, which is registered in the Brazilian Institute of Environment and Renewable Natural Resources (IBAMA) as a nursery of the Brazilian fauna specimens, for scientific purposes (Registration 482,508).

Thus, immediately after euthanasia, one conducted the parietal peritoneum collection, which was washed in $0.9 \% \mathrm{NaCl}$ saline solution to remove dirtiness, blood, and adhered tissues. Subsequently, the peritoneal segments, right and left, were divided into two portions and each of them was packed in a separate sterile glass flask, one containing 300\% supersaturated sugar solution and the other containing $98 \%$ glycerin (manufacturer information). After 48 hours of immersion, the membranes were placed in new solutions at the respective concentrations, since their dehydration promoted the solution dilution. The membrane segments remained totally immersed for preservation and storage, under room temperature, for a period not less than 30 days.

For preparing the $300 \%$ supersaturated sugar solution, according to the methodology employed by [22] one used $300 \mathrm{~g}$ of cane sugar (manufacturer information) in $100 \mathrm{~mL}$ of distilled water, obtaining in the end a solution at 3:1 ratio.

In rats from the control group one performed a median abdominal incision and pulled out an elliptical segment from the abdominal muscles with its aponeuroses, 2 long $\times 1 \mathrm{~cm}$ wide; then, one produced muscle raffia with a continuous simple suture with a 4-0 nylon wire. The decrease in subcutaneous tissue was arranged in zigzag and the skin suture in " $U$ " (Wolff).

In animals from GII and GIII, one pulled out a $2 \times 2 \mathrm{~cm}$ segment from the abdominal wall, promoting its replacement by a fragment, with the same size, of 
the lowland paca's peritoneum membrane, sutured with 4-0 nylon wire in a simple continuous manner. According to the methodology employed by [23], the peritoneum fragments were removed from the flasks 15 minutes before their application, thoroughly washed with $0.9 \% \mathrm{NaCl}$ saline solution, and immersed in a sterile vat containing the saline solution at room temperature for rehydration. The decrease in subcutaneous tissue and the skin suture were performed in the same manner as in the control group.

For the stereological evaluation, the rats were euthanized at the different moments (M7, M15, M30, and M60). One removed $9 \mathrm{~cm}^{2}$ fragments $(3 \times 3 \mathrm{~cm})$ from the interface implantation/native tissue of all animals. These fragments were packed in universal flasks with modified Karnovsky solution (3\% glutaraldehyde and $1 \%$ paraformaldehyde in $0.1 \mathrm{M}, 7.4 \mathrm{pH}$ phosphate buffer) for fixation.

For the histopathological analysis, half of the material already fixed in Karnovsky was included in Histosec (Merck), and the inclusion and staining was performed according to [24]. The material's microtome was obtained in an automatic microtome (Leica-Germany, RM $2155^{1}$ ), resulting in $5 \mathrm{~m}$ sections with the aid of disposable razors collected on glass slides and subject to staining with Hematoxylin and Eosin (HE). All preparations were photo documented in a Leica DM 5000 B light microscope for morphological analysis.

The other half of the material fixed in a modified Karnovsky solution was used for the stereological study. Each sample corresponded to the implantation/native tissue from each animal was sectioned into 10 pieces, resulting in small fractions $0.3 \mathrm{~cm}$ thick each; out of these, 10 were randomly selected and 3 fragments a block sampling fraction $(\mathrm{bsf}=1 / 2)$ was SUR selected obtaining. Those fragments were washed with phosphate buffer solution $(0.1 \mathrm{M}, 7.4 \mathrm{pH})$ for 8 consecutive days to remove excess fixative, afterwards, one conducted the drying material process with $70 \%$ alcohol, followed by its preservation in $80 \%$ alcohol, under refrigeration.

The next step consisted of infiltrating material in a Historesin solution (Leica-Germany) and $80 \%$ alcohol for about 4 hours. Then, each small material fraction was included into a HistoMold for initial polymerization at room temperature for 15 to 30 minutes and a final polymerization in a greenhouse at a $37.5^{\circ} \mathrm{C}$ temperature for 1 week. The microtome of this material was carried out in an automatic microtome (Leica RM 2155), using glass knives, to obtain 6 sections (3 pairs) with $2 \mu \mathrm{m}$ per block at $12 \mu \mathrm{m}$ intervals previously determined through a pilot experiment, which measured the size of the cell under evaluation-section sampling fraction (ssf 4/30,000). After performing this procedure, the sampled sections were collected on slides and subject to HE staining, according to [21].

Subsequently, the material was quantified through a stereological study with a physical disector nature and a fractionator design.

The physical fractionator was used for estimating the total number of mononuclear and polymorphonuclear cells observed in the abdominal wall repair process. Our approach comprised one reference and one look-up section. Thus, the disector height was $12 \mu \mathrm{m}$. An area sampling fraction (asf) of the chosen sec- 
tions was sampled using 2-D unbiased counting frames with a frame area equivalent to $207 \mathrm{~cm}^{2}$ (Gundersen, 1977). Lastlythe total number of particles counted $\left(\Sigma \mathrm{Q}^{-}\right)$, was obtained using two-way physical disectors. Section images used for quantification were obtained through the software Leica Application Suite.

One determined the total number of mononuclear and polymorphonuclear cells having the "fractionator" system as a basis, which represents the total number of inflammatory cells counted through the reverse of sampled fractions [25] [26]. Using this formula:

$$
N=\frac{\sum Q \cdot \mathrm{bsf}^{-1} \cdot \mathrm{ssf}^{-1} \cdot \mathrm{asf}^{-1}}{2}
$$

where:

$N=$ total number of mono or polymorphonuclear cells;

$Q=$ total number of particles sampled by physical dissectors;

bsf: block sampling fraction $(3 / 10)$;

ssf: section sampling fraction $(4 / 30,000)$;

asf: area sampling fraction $(5 / 16)$.

For the stereological study, the total number $(\mathrm{N})$ of each cell type (mononuclear and polymorphonuclear) was analyzed using the completely randomized experimental design with treatments in the factorial scheme (GI, GII, GIII, and M7, M15, M30, M60) with 5 replicates for each crossing of the factor levels.

\section{Statistical Analyses}

ANOVA was conducted and followed by Tukey's test with a 5\% probability, using the software MiniTab.

\section{Results}

Histology: In all samples related to GI, at all moments (M7, M15, M30, and M60), one observed under light microscopy, in the pull out region of the aponeurotic muscle elliptical segment with all layers and posterior suture, presence of fibrous tissue separating the muscle layers, and presence of mixed inflammatory infiltrate around the suture wire, with a predominance of mononuclear and rare polymorphonuclear cells (Figure 1).

In the samples related to the implantations of peritoneum from GII in M7 observed through light microscopy, one found out at the site where the implantation was placed, fibrosis area separated from muscle tissue and presence of adipose tissue, along with a large mononuclear inflammatory infiltrate and rare polymorphonuclear cells. In M15, one found out a mild mixed inflammatory infiltrate with predominance of mononuclear cells around the suture wire and the implantation.

Also in GII, in the samples related to animals from M30, one found out at the site where the implantation was placed the presence of mild fibrous tissue juxtaposed to the muscle layer with mononuclear cell inflammatory infiltrate. In M60, one found out in the implantation/native tissue interface the presence of 
abundant fibrous tissue interspersed with the muscle layer followed by mild mononuclear cell inflammatory infiltrate (Figure 2).

In the samples related to the implantations of lowland paca's peritoneum from GIII in M7 and M15, one found out the presence of adipose tissue, disruption of muscle layers bound by fibrous tissue along with mild mixed inflammatory infiltrate with a predominance of mononuclear and rare polymorphonuclear cells.

Also in GIII, in M30, one found out the presence of mild fibrous tissue juxtaposed to the muscle layer. The mononuclear inflammatory infiltrate was observed at the site where the implantation has been placed, too. In M60, one found out the presence of intense fibrous tissue interspersed with muscle layer. Amidst the fibroblasts, one noticed the presence of muscle bundles and mild mononuclear cells (Figure 3).

Stereology: The total number of polymorphonuclear cells was zero.Through the $\mathrm{F}$ test of variance analysis in the evaluation of the mononuclear cell number, the interaction group $\times$ time wasn't significant $(p=0.131)$, i.e., in general, the groups had the same behavior over time (Figure 4). However, analyzing this interaction, a significant difference was found between the groups at the $7^{\text {th }}$ and $15^{\text {th }}$ post-operatory day, according to the interaction graph (Figure 4).

In isolation, it's possible to interpret the significance between groups ( $\mathrm{p}=$ 0.0006). In GII, the number of mononuclear cells was higher than that of GI and GIII (Figure 5).

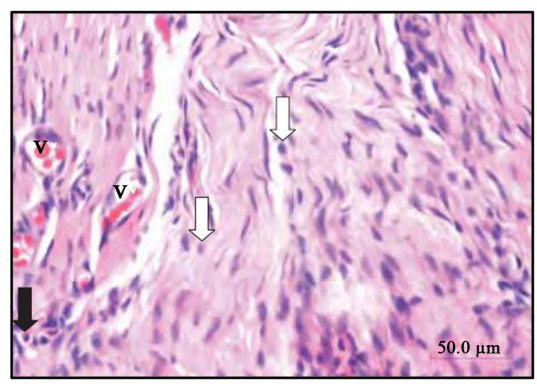

Figure 1. Photomicrograph of Group GI at 60 days of postoperative period (M60), note the presence of infiltrates inflammatory represented by polymorphonuclear cells (black arrow) and lymphocytes (arrow white), next to the fibrous tissue (rosea) and vessels (V) (Paraplast, HE, 40×).

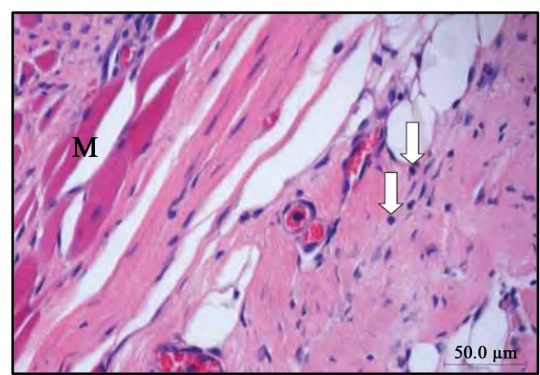

Figure 2. Photomicrograph of Group GII at 60 days of postoperative period (M60), note the presence mononuclear inflammatory infiltrate (arrow) next to the fibrous tissue (rosea) and muscle (M), (Paraplast, HE, 40×). 


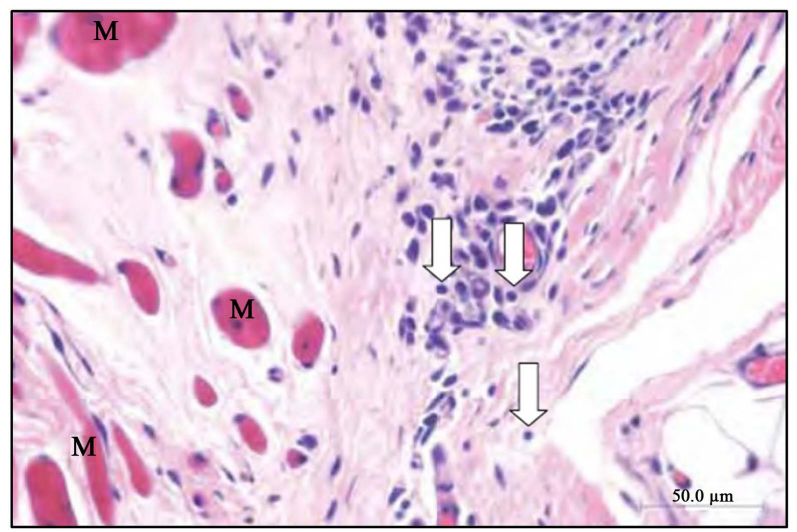

Figure 3. Photomicrograph of Group GIII at 60 days of postoperative period (M60), the presence of muscle (M) and lymphocytes (arrows) is observed next to the fibrous tissue (rosea) (Paraplast, HE, 40×).

Interaction between group and time for mononuclear cells

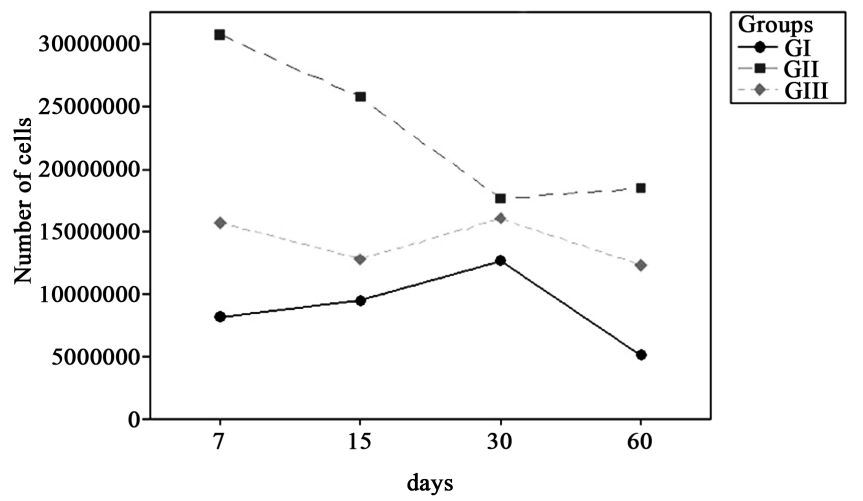

Figure 4. Graph of the group $\times$ time interaction for the average mononuclear cell count. Groups followed by the same letters at different moments don't differ from each other through $5 \%$ Tukey test.

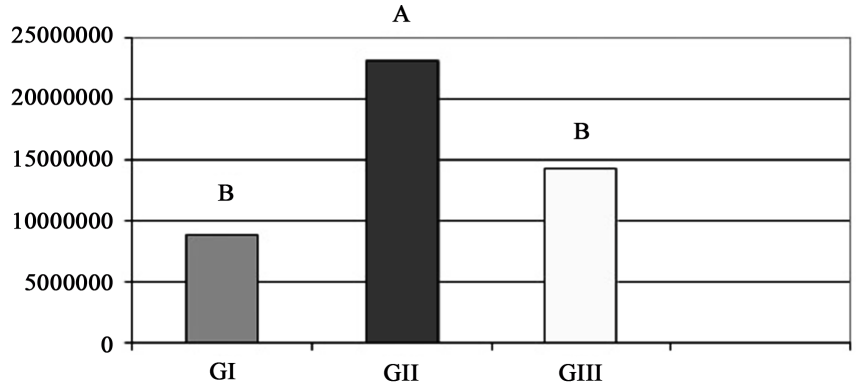

Figure 5. Graph of the average number of mononuclear cells in groups without taking into account the evaluation moment. Groups followed by the same letters at different moments don't differ from each other through 5\% Tukey test.

\section{Discussion}

The lowest count of inflammatory cells in the control group (GI), at all evaluation moments (M7, M15, M30 and M60), supports the observations by [27] [28] when they state that nylon causes mild tissue reaction. 
The occurrence of inflammatory infiltrate with a predominance of mononuclear cells identified in GI, at all moments (M7, M15, M30, and M60) was also observed by Rahal et al. (1997) [29] when using the surgical nylon wire and "sterilized fishing line" on the abdominal wall of rats.

In general, in both groups receiving the peritoneum of paca (GII and GIII), as well as observed by Leal et al. (2014) [15] in qualitative histological study in the use of the peritoneum of paca implanted in rats, it was demonstrated the acute inflammatory reaction (M7 and M15) which gradually decays over the days (M30 and M60).

The presence of mononuclear cells in GII and GIII at all moments under study was also identified by [5], in a study on the canine pericardium preserved in a supersaturated salt solution implanted on the abdominal wall in Wistar rats. In this study, the authors noticed a higher concentration of mononuclear cells at the early moments, with a progressive decrease until the last evaluation period. These authors also report that the inflammatory response by polymorphonuclear cells was abundant within the period of three days after the surgical procedure, however, this moment wasn't evaluated in the study concerned; thus, rare polymorphonuclear cells were identified in this opportunity.

In animals from GII and GIII receiving the lowland paca's peritoneum the occurrence of acute inflammatory reaction (M7 and M15) was demonstrated, which was gradually disappearing and the membrane was replaced by fibrous connective tissue interspersed with muscle tissue (M30 and M60). Such response pattern was evidenced in studies on different preserved biological materials, both in glycerin and in the supersaturated sugar solution [3] [4] [22]. It's known that the biological membranes act as a skeleton for the living tissue growth [1] and, thus, the lowland paca's peritoneum also had this performance, regardless of the medium where they were preserved.

The stereological evaluations were crucial for the comparative analyses between the results observed in each group under study, since they allowed quantifying the changes identified [16]. As the fields for stereological analysis were systematically randomized, the polymorphonuclear cell count was zero, unlike the histological analysis done by Leal et al. (2014), where one found out the presence of rare polymorphonuclear cells in M7 and M15.

The exclusive presence of mononuclear cells, in all groups at all moments, is justified by the usual inflammatory response which is observed in wound healing by first intention, where the number of polymorphonuclear cells is identified up to the $3^{\text {rd }}$ day, being replaced by mononuclear cells, which progressively decrease insofar as the healing process occurs [27] [30]. However, one should take into account that in this opportunity the first evaluation moment was conducted at the $7^{\text {th }}$ post-operatory day and, thus, one didn't identified a significant presence of polymorphonuclear cells.

Stereology allowed the quantitation of overall results observed in histology by Leal et al. (2014) [15] with regard to the decrease in inflammatory response during the post-operatory evaluation moments [27] [30]. 
The increase in inflammatory cells observed through histology in animals from GII in M30 when compared to the other groups studied here at the same evaluation moment wasn't statistically significant through stereological analysis.

Mota et al. [31] and BarianiJúnior et al. [32] stated that 300\% sugar solution and $98 \%$ glycerin are similar preservation media because they maintain cell integrity; notwithstanding, this similarity can't be supported when evaluating preservatives, due to the host's inflammatory response, because there was a statistically significant difference between the groups, by identifying a higher inflammatory infiltrate in animals from GII when compared to GIII.

Leal et al. (2014) [15] conclude in their quantitative study, when compared the peritoneum of paca preserved in 300\% supersaturated sucrose solution or $98 \%$ glycerine, that although healing and adverse reactions were statistically similar in both groups, the preservation of the membrane in $300 \%$ supersaturated sucrose solution allowed better flexibility during surgery when compared to membrane storage in $98 \%$ glycerin. However when quantifying the inflammatory response there is significant difference between the groups receiving the membrane, and according to the inflammatory response, the peritoneum preserved in glycerine showed better result because has less inflammatory reaction and there is no statistical difference when compared to control group.

\section{Conclusion}

Due to the way this experiment was conducted, one can conclude that the lowland paca's peritoneum as a biological membrane preserved in $98 \%$ glycerin when implanted on the abdominal wall of rats enabled a lower inflammatory response than the group that received the peritoneum of paca preserved in 300\% sucrose. However, due to the late onset of the evaluations (7 postoperative days), further studies should be performed to confirm such analyzes.

\section{Acknowledgements}

This work received financial support from São Paulo Research Foundation (FAPESP-Process number: 2010/13243-0).

\section{Conflicts of Interest}

The authors declare no conflicts of interest regarding the publication of this paper.

\section{References}

[1] Alvarenga, J. (1992) Possibilidades e limitações da utilização de membranas biológicas preservadas em cirurgia. In: Daleck, C.R., Baptista, L.C. and Mukai, L.S., Eds., Tópicos em cirurgia de cães e gatos, Funep-Unesp, Jaboticabal, 33-42.

[2] Mota, F.C.D., Eurides, D., Freitas, P.M.C., Beletti, E., Mastrantonio, E.C., Shimizu, B.J., Silva, L.A.R., Cardoso, J.R. and Martins, A.K. (2002) Análise Ultra-Estrutural da túnica muscular do intestino delgado de cães preservado em diferentes meios. Brazilian Journal of Veterinary Research and Animal Science, 39, 13-17. https://doi.org/10.1590/S1413-95962002000100002 
[3] Pigossi, N. (1964) Implantação de Dura-Máter homógena conservada em glicerina-estudo experimental em cães. Ph.D. Dissertation, Universidade de São Paulo, São Paulo.

[4] Daleck, C.R., Daleck, C.L.M., Gandolfi, W. and Alessi, A.C. (1987) Esofagoplastia cervical no cão com peritônio autólogo ou homólogo conservado em glicerina- "Estudo Experimental”. Ars Veterinária, 3, 195-202.

[5] Brun, M.V., Pippi, N.L., Dreimeier, D., Contensini, E.A., Beck, C.A.C., Cunha, O., Pinto Filho, S.T.L., Roehsig, C. and Stedile, R. (2002) Solução hiperstaurada de sal como conservante de pericárdio canino utilizado na reparação do músculo reto abdominal de ratos Wistar. Ciência Rural, 32, 1019-1025.

https://doi.org/10.1590/S0103-84782002000600016

[6] Saporito, W.F., Pires, A.C., Cardoso, S.H., Correa, J.A., Abreu, L.C., Valenti, V.E., Miller, L.M.R. and Colombari, E. (2011) Bovine Pericardium Retail Preserved in Glutaraldehyde and Used as a Vascular Patch. Biomedcentral Surgery, 11, 37. https://doi.org/10.1186/1471-2482-11-37

[7] Sarac, T.P., Carnevale, K., Smedira, N., Tanquilut, E., Augustinos, P., Patel, A., Naska, T., Clair, D. and Ouriel, K. (2011) In Vivo and Mechanical Properties of Peritoneum/Fascia as a Novel Arterial Substitute. Journal of Vascular Surgery, 41, 490-497. https://doi.org/10.1016/j.jvs.2004.11.033

[8] Barbosa, R.R., Leal, L.M., Martins, L.L., Garcia Filho, S.P. and Machado, M.R.F. (2012) Estrutura e Ultra-Estrutura de membranas biológicas de ovinos da raça Santa Inês (Ovis aries, L., 1758) a fresco e conservadas em glicerina. Biotemas, 25, 97-107. https://doi.org/10.5007/2175-7925.2012v25n2p97

[9] Camargo, A.D., Leal, L.M.,Garcia Filho, S.P., Martins, L.L., Reis, A.C.G. and Machado, M.R.F. (2012) Propriedades morfológicas do peritônio da paca (Cuniculus paca, L. 1766) a fresco e conservados em glicerina 98\%. Biotemas, 25, 187-194. https://doi.org/10.5007/2175-7925.2012v25n4p185

[10] Redford, K.H. and Robinson, J.G. (1991) Subsistence and Commercial Uses of Wildlife in Latin America. In: Robinson, J.G. and Redford, K.H., Eds., Neotropical Wildlife Use and Conservation, The University of Chicago Press, Chicago, 6-23.

[11] Eisenberg, J.F. and Redford, K.H. (1999) Mammals of the Central Neotropics: Ecuador, Peru, Bolivia, Brazil. The University of Chicago Press, Chicago.

[12] Lange, R.R. and Schmidt, E.M.S. (2007) Rodentia: Roedores Silvestres (Capivara, Cutia, Paca, Ouriço). In: Cubas, Z.S., Silva, J.C.R. and Catão-Dias, J.A., Eds., Tratado de animais selvagens. Medicina veterinária, Roca, São Paulo, 475-491.

[13] Queirolo, D., Vieira, E., Emmons, L. and Samudio, R. (2010) Cuniculus paca. IUCN Red List of Threatened Species. http://www.iucnredlist.org

[14] Santos, B.F. (2006) Modelo Animal. In: Andrade, A., Pinto, S.C. and Oliveira, R.S., Eds., Animais de laboratório: Criação e experimentação, Fiocruz, Rio de Janeiro, 23-24.

[15] Leal, L.M., Ferreira, A.R.S., Reis, A.C.G., Martins, L.L., Garcia Filho, S. and Machado, R. (2014) O uso do peritônio de pacaconservadoemsoluçãosupersaturada de açúcar a $300 \%$ ouglicerina a $98 \%$ implantados na parede abdominal de ratos [The use of Paca Peritoneum Preserved in Supersaturated Sugar Solution 300\% or Glycerine $98 \%$ Implanted in the Abdominal Wall of Rats]. ArquivoBrasileiro de Medicina Veterinária e Zootecnia, 66, 1383-1391. https://doi.org/10.1590/1678-6703

[16] Weibel, E.R. (1979) Stereological Methods Vol. 1: Practical Methods for Biological Morphometry. Academic Press, London. 
[17] Cruz-Orive, L.M. (1997) Stereology of Single Objects. Journal Microscopy, 186, 93-107. https://doi.org/10.1046/j.1365-2818.1997.1380695.x

[18] DeHoff, R.T. (2000) Probes, Populations, Samples, Measurements and Relations in Stereology. Image Analysis \& Stereology, 19, 1-18. https://doi.org/10.5566/ias.v19.p1-8

[19] West, J.M. (2012) Topic Introduction to Stereology. Cold Spring Harbor Protocols, 8, 843-851

[20] Ribeiro, A.A., Lacerda, P.M.O., Melo, M.P., Balieiro, J.C. and Souza, R.R. (2008) Placental Microstructure and Efficiency in Cloned Bovines: A Design-Based Stereological Approach. Cell and Tissue Research, 33, 105-114. https://doi.org/10.1007/s00441-008-0626-4

[21] Shirazi, M., Noorafshan, A. and Serhan, A. (2012) Effects of Different Suture Materials Used for the Repair of Hypospadias: A Stereological Study in a Rat Model. Urologia Internationalis, 89, 395-401. https://doi.org/10.1159/000343423

[22] Mazzanti, A., Pippi, N.L., Raiser, A.G., Graça, D.L., Faria, R.X., Oliveira, L.O. and Guimarães, L.D. (2001) Músculo diafragma homólogo conservado em solução supersaturada de sacarose para a reparação de grande defeito na diafragma de cão. Ciência Rural, 31, 277-283. https://doi.org/10.1590/S0103-84782001000200014

[23] Daleck, C.R., Alessi, A.C. and Costa-Neto, J.M. (1988) Substituição de um retalho diafragmático de cão por peritônio de bovino conservado em glicerina: Estudo experimental. Ars Veterinária, 4, 53-61.

[24] Behmer, A.O., Tolosa, E.M.C. and Freitas-Neto, A.G. (1976) Manual de técnicas para histologia normal e patológica. Edart, São Paulo.

[25] Gundersen, H.J.G. (2002) The Smooth Fractionator. Journal Microscopy, 207, 191-210. https://doi.org/10.1046/j.1365-2818.2002.01054.x

[26] Turiel, M.C.P. (2011) Encefalite Viral Induzida Pelo vírus da dengue em camundongos suíços albinos: A resposta inflamatória no sistema nervoso central do hospedeiro neonato. M.S. Dissertation, Universidade Federal do Pará, Belém.

[27] Turner, A.S. and Mcilwraith, C.W. (1985) Materiais de sutura e agulhas. In: Turner, A.S. and Mcilwraith, C.W., Eds., Técnicas cirúrgicas em animais de grande porte, Roca, São Paulo, 67-77.

[28] Boothe, H.W. (2007) Fios de sutura, adesivos de tecidos, grampeadores e clipes hemostáticos. In: Slatter, D., Ed., Manual de Cirurgia de Pequenos Animais, Manole, Barueri, 235-243.

[29] Rahal, S.C., Rocha, N.S., Figueiredo, L.A. and Iamaguti, P. (1997) Estudo comparativo das reações teciduais produzidas pela "linha de pesca" (poliamida) e fio de náilon cirúrgico. Ciência Rural, 28, 89-93. https://doi.org/10.1590/S0103-84781998000100015

[30] Cotran, R.S., Kumar, V. and Collins, T. (2000) Patologia Estrutural e Funcional. Guanabara Koogan, Rio de Janeiro.

[31] Mota, F.C.D., Eurides, D., Freitas, P.M.C., Beletti, E., Mastrantonio, E.C., Shimizu, B.J., Silva, L.A.R., Cardoso, J.R. and Martins, A.K. (2003) Análise morfológica e microbiológica utilizando-se diferentes métodos de preservação sobre a camada muscular do intestino delgado de cães. Ciência Animal Brasileira, 4, 117-123.

[32] BarianiJúnior, A.F., Guimarães, G.C. and Ferracini Júnior, R. (2007) Análise microbiológica de diferentes meios de conservação utilizados para preservar membranas biológicas bovinas. $15^{\circ}$ Simpósio Internacional de Iniciação Científica da USP, São Paulo. http://www.usp.br/siicusp/Resumos/15Siicusp/2383.pdf 